\title{
CONDITIONAL FEE AGREEMENTS IN NORTHERN IRELAND: GIMMICK OR GODSEND?
}

\author{
Annette Morris, Lecturer, Cardiff Law School*
}

The Access to Justice (Northern Ireland) Order 2003 provides the legislative platform for the introduction of conditional fee agreements (CFAs) in Northern Ireland. ${ }^{1}$ CFAs were first allowed by a Conservative Government in England and Wales in 1995. ${ }^{2}$ They were initially introduced to complement legal aid by facilitating access to justice for those who neither satisfied the eligibility criteria, nor could afford to fund their claims privately. Whilst in opposition, the Labour Party dismissed CFAs as a "gimmick". ${ }^{3}$ In Government, however, it has capitalised on the development of a CFA market to justify the withdrawal of legal aid from certain categories of claim. ${ }^{4}$ The Access to Justice Act 1999 provided for the withdrawal of legal aid for claims relating to negligently caused personal injury and death, excluding clinical negligence claims, on the assumption that they could be funded by CFAs instead. ${ }^{5}$

* I am grateful to Professor Richard Moorhead, Professor Richard Lewis, Professor Nigel Lowe and Dr Sara Drake for their comments on earlier drafts of this article. I take sole responsibility for the views expressed and for any errors or omissions.

1 SI 2003/435 (N.I.10), articles 38 and 39.

2 Section 58 of the Courts and Legal Services Act 1990 (c.41) declared that CFAs relating to proceedings specified by order of the Lord Chancellor would "not be unenforceable by reason of its being a conditional fee agreement". The Lord Chancellor specified in the Conditional Fee Agreements Order 1995 (SI 1995/1674) that CFAs could be enforceable in claims relating to death, personal injury and insolvency and for proceedings before the European Court of Human Rights. The Conditional Fee Agreements Order 1998 (SI 1998/1860) replaces the 1995 Order and allows CFAs in all civil claims, except specified family proceedings.

3 Abel, English Lawyers Between Market and State: The Politics of Professionalism (2003), at p.294.

4 It largely justified this on the basis of unsustainable increases in legal aid expenditure. Net expenditure on legal aid in England and Wales had increased by $115 \%$ within six years, from $£ 682$ million in $1990-1991$ to $£ 1,477$ million and legal aid in civil cases almost tripled: Access to Justice with Conditional Fees - A Lord Chancellor's Department Consultation Paper (1998), at para.1.4. In Northern Ireland, legal aid expenditure had increased from £12.9 million in 1990-1991 to $£ 28.85$ million in 1997-1998: Public Benefit and the Public Purse - Legal Aid Reform in Northern Ireland (1999), at para.1.3. See further: Zander, "The Government's Plans on Legal Aid and Conditional Fees" (1998) 61 M.L.R 538; Moorhead, "Conditional Fee Agreements, Legal Aid and Access to Justice" (1999) 33(2) U.B.C.Law Review 471 and Capper, "Personal Injury Litigation - The Case for Legal Aid” (2002) 53 N.I.L.Q 137, at p.138.

5 Schedule 2, para.1 of the Access to Justice Act 1999 (c.22) excludes public funding for claims relating to "allegations of negligently caused injury, death or damage to property, apart from allegations relating to clinical negligence." Clinical negligence claims remained within the scope of legal aid because it was feared that the CFA market at the time would not be able to cope with their complexity and expense: Access to Justice with Conditional Fees, ibid., at para.3.16. There are now 
CFAs will initially complement, rather than replace, legal aid in Northern Ireland, although it is not clear whether legal aid will be available regardless of the availability of CFAs or only in those cases where a CFA would not be viable. ${ }^{6}$ The Access to Justice (Northern Ireland) Order 2003 does provide, however, for the withdrawal of legal aid from certain categories of claim at a later stage. ${ }^{7}$ It seems inevitable, therefore, that the Government will be looking to shift responsibility for the funding of personal injury claims from the state to the CFA market once it is sufficiently developed.

The introduction of CFAs in Northern Ireland signifies the Government's belief that they have been a successful means of funding claims and a viable alternative to legal aid in England and Wales. It has done little, however, to establish this. During the consultation process leading to the Order, the Government stated on more than one occasion that it could draw both on experience of and research into CFAs in England and Wales. ${ }^{8}$ It failed, however, to provide any evidence from England and Wales in support of its' reforms and whilst, on occasion, it made vague claims that CFAs were working well and had extended access to justice, these were unsubstantiated. ${ }^{9}$

The implementation of the Order began with the establishment of the Northern Ireland Legal Services Commission in September 2003, which is responsible for the administration of legal aid and for the implementation of remaining reforms required by the Order. ${ }^{10}$ Whilst it is currently focusing on the legal aid reforms, ${ }^{11}$ it is expected to turn its attention to the introduction

moves, however, to refuse legal aid for such claims where they could be conducted on a CFA basis instead: Legal Services Commission, A New Focus for Civil Legal Aid - Encouraging Early Resolution, Discouraging Unnecessary Litigation (2004), at para. 4.23. See also, "Miracle Cure or Truly Terrifying?" (2004) 31 Litigation Funding 2.

6 Public Benefit and the Public Purse, op. cit, n.4 above, at para.8.10.

7 Article 12(6).

8 Public Benefit and the Public Purse, op.cit., n.4 above, at para. 8.4; Rosie Winterton, Parliamentary Secretary, Lord Chancellor's Department in evidence to the Northern Ireland Grand Committee, Hansard (House of Commons), 24 October 2002, at col. 003 and in evidence to the Third Standing Committee on Delegated Legislation, Hansard (House of Commons), 23 January 2003, at col. 006.

9 Rosie Winterton, Parliamentary Secretary, Lord Chancellor's Department in evidence to the Northern Ireland Grand Committee, ibid., at col. 007 and Lord Bach, Parliamentary Secretary, Lord Chancellor's Department in evidence to the House of Commons Northern Ireland Affairs Committee: Legal Aid in Northern Ireland, Fourth Report of the Northern Ireland Affairs Committee (2001), para.24 of Minutes of Evidence.

10 The Commission, which is an executive non-departmental body, assumed responsibility for the administration of legal aid from the Law Society of Northern Ireland on 1 November 2003. It comprises ten members, with predominantly a civil service background. Concern has been expressed that the Commission does not contain solicitors with recent experience of private practice: Bailie, "Coming Soon. .." The Writ, October 2003, at p.4. Until the implementation of the legal aid reforms, the Commission will continue to administer legal aid in accordance with the Legal Aid, Advice and Assistance (Northern Ireland) Order 1981 (SI 1981/228 (N.I.8)) and the Legal Aid (Financial Conditions) Regulations (Northern Ireland) 2003 (SR 2003/88).

11 Articles 10-20 of the Order provide for the separation of the legal aid budgets for civil and criminal legal services. Whilst the budget for criminal legal services will 
of alternative funding mechanisms, including CFAs, shortly. ${ }^{12}$ The intervening period provides a useful opportunity to examine the operation of CFAs in England and Wales and to consider whether experience to date does indeed suggest that CFAs should be introduced in Northern Ireland. This paper concentrates on these two issues. In noting that the CFA market's capacity to facilitate access to justice is still unclear, as are the wider implications of CFAs, it is argued that the Government should proceed cautiously until more is known in these respects. In addition, whilst experience in England and Wales should inform the CFA debate in Northern Ireland, it cannot replace the need for empirical research into personal injury litigation and the economic capacity of the legal market to assess the viability of CFAs within the jurisdiction.

\section{Part One: The Operation Of Conditional Fee Agreements With Recoverability In England And Wales}

CFAs allow lawyers to act for personal injury claimants on, what is commonly referred to as, a 'no win, no fee' basis. Under a CFA, if a claimant loses her claim, she is not liable to pay her lawyer for the work completed on her behalf. If, however, she wins, she is liable to pay not only her lawyer's normal fees, but also an uplift of them. The amount of the uplift, which is called the 'success fee', is agreed between the lawyer and the claimant at the time of entering the CFA and is expressed as a percentage of the lawyer's normal fees. It is intended to reward the lawyer for taking the risk of not being paid and for funding the claim until its conclusion. They have most commonly been used to fund personal injury claims and their development has been assisted by the emergence of after-the-event legal expenses insurance (ATE insurance). ${ }^{13}$ This provides costs protection in the event of losing, as whilst a losing claimant is not liable to pay her own lawyer under a CFA, she remains liable to pay the other side's costs in accordance with the 'loser pays' principle.

In seeking to encourage the use of CFAs, the Government introduced the concept of 'recoverability' within the Access to Justice Act 1999. Success fees and ATE insurance premiums are now recoverable from losing defendants (or, in reality, their liability insurers) in the same way as claimants' lawyers fees and disbursements. ${ }^{14}$ This is "an interesting attempt

continue to be determined on a demand-led basis, the budget for civil legal services will be capped and targeted towards priority cases. The Commission is currently undertaking research to establish the level at which the budget should be capped and to determine which cases are of sufficient priority to receive legal aid: Northern Ireland Legal Services Commission, Corporate Plan: 2004-2007 (2004).

12 Corporate Plan, ibid.

13 For further information on the operation of CFAs in their early stages, see Yarrow, The Price of Success: Lawyers, Clients and Conditional Fees (1997); White and Atkinson, "Personal Injury Litigation, Conditional Fees and After-the-Event Insurance" (2000) 19 C.J.Q 118; Yarrow and Abrams, Nothing to Lose? Clients' Experiences of Using Conditional Fees (2000) and Yarrow, Just Rewards? (2000).

14 Section 58A(6), Courts and Legal services Act 1990 (as amended by section 27, Access to Justice Act 1999) and section 29, Access to Justice Act 1999 respectively. See further: Lord Chancellor's Department Consultation Paper, 
to squeeze public provision into a private model approach", as these costs had previously been met from claimants' damages in winning claims. ${ }^{15}$

The proposed introduction of CFAs in Northern Ireland has provoked widespread concern and controversy for a number of reasons. ${ }^{16}$ Personal injury claims are a central feature of civil justice in Northern Ireland with, on average, just over 40,000 claims pursued each year. ${ }^{17}$ As CFAs are not subject to financial eligibility criteria, they appear to facilitate access to justice on a universal basis. There is some scepticism, however, about whether access to justice can or should be met by the vagaries of a CFA market. ${ }^{18}$ There are also concerns about the wider implications of CFAs. CFAs are considered undesirable because they create a conflict of interest between lawyers and their clients, as lawyers have a direct interest in the outcome of the claim, which might encourage under-settling or other ethically dubious behaviour. ${ }^{19}$ It has also been suggested that CFAs lead to an increase in the number of claims pursued ${ }^{20}$, to an explosion of unregulated claims management companies ${ }^{21}$ and to increased legal costs and insurance premiums $^{22}$. It is these issues which are explored below in relation to

Conditional Fees: Sharing the Risks of Litigation (1999) and the Government's response (2000).

15 Moorhead, "CFAs: A Weightless Reform of Legal Aid?" (2002) 53 N.I.L.Q. 153, at p.154.

16 This was acknowledged by the Government: Northern Ireland Court Service, The Way Ahead - Legal Aid Reform in Northern Ireland (2000), at p.11. As an alternative to CFAs, the legal profession called for the establishment of a publiclyfunded contingency legal aid fund (CLAF). This would have met plaintiffs' legal costs and whilst this would require an initial injection of public funds, it would, it was suggested, have become self-financing, as the fund would be replenished by costs recovered in winning cases. See further: Report by the Lord Chancellor's Legal Aid Advisory Committee on The Viability of Establishing a Contingency Legal Aid Fund or Conditional Fees in Northern Ireland (2001); Capper, op. cit., n. 4 above and Capper, "The Contingency Legal Aid Fund - A Third Way to Finance Personal Injury Litigation" (2003) 30 Journal of Law and Society 66. The Government rejected the proposed publicly-funded CLAF, although article 40 of the Access to Justice (Northern Ireland) Order 2003 contains a legislative power to introduce a privately funded CLAF. Whilst it did not explain its' rejection in relation to Northern Ireland, it has since explained its aversion to a publicly funded CLAF in England and Wales: Department for Constitutional Affairs, Making Simple CFAs A Reality (2004), at p.33.

17 Data on the number of claims has been obtained from the Compensation Recovery Unit (Northern Ireland). Pursuant to the Social Security (Recovery of Benefits) (Northern Ireland) Order 1997 (SR 1997/1183 (N.I.12)), the Unit recovers from the 'compensator' - the defendant or insurer - amounts equivalent to social security benefits paid as a result of an accident, injury or disease. In ensuring that all due sums are recovered, compensators are obliged to notify the Unit of all personal injury claims, details of which are entered onto the Unit's database.

18 See further Capper, op.cit., n.4 above, at pp.137-142.

19 The Way Ahead, op. cit., n.16 above, at p.21. See also Capper, op. cit., n.4 above, at pp.145-6.

${ }^{20}$ Lord Laird, Hansard (House of Lords), 6 February 2003, col. 355.

21 Law Society of Northern Ireland's submissions to Northern Ireland Assembly, which are attached to the Assembly's Ad Hoc Committee Report on the draft Access to Justice (Northern Ireland) Order 2002 (2002).

22 Capper, op. cit., n.4 above, at p.144. 
England and Wales. As CFAs will operate with recoverability in Northern Ireland and are intended, in the long term, to be a replacement for legal aid for certain types of claim, this paper focuses on the operation of CFAs with recoverability in England and Wales since the implementation of the Access to Justice Act 1999.

\section{Are Conditional Fee Agreements Facilitating Access To Justice?}

\section{Access to Justice and Market Incentives}

Considering whether CFAs facilitate access to justice raises the inevitable question: what constitutes 'access'? Answering this question is difficult because, as Cappelletti notes, "[e]veryone has his own conception by what is meant". 23 The term is used as shorthand for a "bundle of problems and a variety of goals" 24 and it generates a "constant debate about how much access to provide and what kind of justice should result". ${ }^{25}$ As Moorhead and Pleasence explain, ${ }^{26}$ the concept is grounded in the notions that there should be equality before the law and that "the possession of rights is meaningless without mechanisms for their effective vindication". ${ }^{27}$ Rather than seeking to define 'access', Cappelletti identifies various 'barriers' which potentially inhibit the achievement of it. ${ }^{28}$ In the context of a claim for personal injury compensation, three such barriers are: ${ }^{29}$

- the ability to secure legal advice and representation, which traditionally depends on the ability to pay for the service;

- the ability to pay disbursements, which are central to the progression of the claim, including fees for expert opinions and court fees;

- the ability to pay defendants' legal costs in the event that the claim is lost.

The 'no win - no fee' aspect of CFAs generates the false perception that they remove all potential financial barriers to pursuing a claim, and as a result, achieve equality before the law. This is only true, however, to the extent that claimants' ability to secure legal advice and representation no longer depends on their ability to pay lawyers. The ability to pay disbursements and to meet defendants' legal costs are still live issues. For CFAs to facilitate access to justice, the CFA market must respond to remove the barriers identified, as otherwise many claimants will be precluded from pursuing their claims because they do not have the financial means to do so. The

23 Cappelletti and Garth (eds.), Access to Justice, Volume 3: Emerging Issues and Perspectives (1979), at p.8.

24 ibid., at p.7.

25 Cappelletti et al (eds.), Access to Justice and the Welfare State (1981), at p.2.

26 Moorhead and Pleasence, "Access to Justice after Universalism: Introduction" (2003) 30 Journal of Law and Society 1.

27 Cranston, 'Rights in Practice' in Sampford and Gilligan (eds.) Law, Rights and the Welfare State, (1986).

28 Op. cit., n.23 above.

29 For further information on why justiceable issues are not always pursued, see Genn, Paths to Justice: What People Do and Think About Going to Law (1999) and Pleasence et al, Causes of Action: Civil Law and Social Justice (2004). 
extent to which the barriers are removed depends, in turn, on the extent to which:

- lawyers respond to the incentive of recovering success fees in winning cases and agree to act on a conditional fee basis;

- insurers respond to the incentive of recovering premiums by providing ATE insurance to cover the risk of paying opponents costs where the claimant loses;

- lawyers, ATE insurers or other third parties invest in claims by assisting claimants with the cost of disbursements and ATE premiums in exchange for a return on that investment.

\section{Political Spin v Economic Reality}

The Government has suggested that the market will respond to incentives in 'good' cases, stating that the "great advantage of the conditional fee system" is that "if you have a good case there is no reason why you should not get justice". ${ }^{30}$ In referring to a good case, it is generally accepted that the Government is referring to cases with prospects of success above fifty per cent. Aligning the extent to which the market will respond with the legal merits of a claim is, however, both over-simplistic and misleading. CFAs involve a number of risks and uncertainties, as follows: ${ }^{31}$

- whether the claim will be won;

- the work and expense that will be required to win the claim;

- the amount of the fee that will be recovered for the work conducted, as this is decided retrospectively at the end of the claim;

- whether a fee will be recovered for the work done on the claim, even if the claim is won;

- the amount of time that will pass before any fee is recovered.

Only some of these are related to whether the case is good in the Government's terms. In deciding whether to act on a CFA basis, lawyers must assess these risks and consider whether they are able and willing to take them and their decisions will largely depend on two factors. Firstly, whether the risks justify the potential returns and secondly, whether the firm's financial position allows the lawyer to take the risks.

Under legal aid, personal injury lawyers secured a relatively constant and stable stream of income as they could claim payments on account for their work and were paid whether claims succeeded or failed. ${ }^{32}$ In this context, the likely length and cost of claims were largely irrelevant. In stark contrast, as lawyers working on a CFA basis do not receive any payments for their work

30 Lord Bach, op. cit., n.9 above.

31 Kritzer, "Seven Dogged Myths Concerning Contingency Fees" (2002) 80 Washington University Law Review 739; Kritzer, Rhetoric and Reality. . .Uses and Abuses. . .Contingencies and Certainties: The American Contingent Fee in Operation (1996).

32 Although they were generally paid less in losing cases. 
until the claim is concluded, if they are paid at all, CFAs pose significant cash flow difficulties for them and the potential length and cost of claims are of central importance. ${ }^{33}$ Lawyers must consider whether their firm's cash flow allows them to invest the time and money necessary in a claim, including disbursements, for its full duration. If the claim could take some time to resolve or is complex and will require considerable investment, the firm's cash flow may not permit the lawyer to take the claim, even if it is good. ${ }^{34}$

In addition, the lawyer must also consider whether the firm can absorb the cost of losing a claim. Lawyers often refer to building a 'war chest' in CFA cases to meet the cost of those cases that lose and they are entitled to charge success fees of up to 100 per cent of their normal fees to achieve this. ${ }^{35}$ If lawyers suspect there may be insufficient money in that war chest to absorb the cost of losing cases, again, lawyers may have to refuse to pursue the claim on a CFA basis. The size of the war chest largely depends on the amount of success fees recovered from other cases. This, in turn, depends on the amounts recovered in winning cases and the success rate of the firm. The decision about whether to support a case is not made in isolation, but with reference to the firm's financial position, its current profile of cases and its past experience. If, for example, a firm has recently lost a large claim, this may affect the extent to which the firm can take risks in new cases in the near future. ATE insurers have to consider similar risks and uncertainties but, of course, it is defendants' costs that are relevant to them.

An understanding of the actual risks involved and the way in which those risks are approached by the CFA market reveals that CFAs are much more complex than political spin suggests. ${ }^{36}$ It is the economic merits, not the legal merits, of the claim that are relevant. Lawyers and insurers consider claims in terms of the risks they pose. The ability to achieve access to justice in personal injury claims now depends, not on the financial position of the claimant, but on the financial ability of both lawyers and ATE insurers to engage in risk. Whilst KPMG's model of an entrepreneurial firm predicted that CFAs would be profitable for small, medium and large firms within three years, ${ }^{37}$ Shapland et al's survey of solicitors' firms raised cause for concern. ${ }^{38}$ Their research suggested that CFAs would work well for straightforward cases, such as road traffic accidents and simple accident at work claims, but not for those cases involving significant questions of liability and serious injury, as lawyers would find it difficult to invest the

33 Mark Harvey, leading personal injury solicitor and costs expert, estimates that the impact on firms' cash flow could be as much as $£ 500$ per claim, which, he states, in a busy practice would mean a potential loss of between $£ 30,000$ to $£ 80,000$ in a single year: Harvey Guide to Conditional Fee Agreements (2002), at p.7.

34 Shapland et al found that a significant number of respondents had refused CFAs because of the impact of cash flow on their practice: Affording Civil Justice (1998), at p.4.

35 Conditional Fee Agreements Order 2000 (SI 2000/823).

36 Claimants also find CFAs complex and difficult to understand: Yarrow and Abrams, op. cit., n.13 above. The Government is seeking, however, to simplify CFAs, see: Making Simple CFAs a Reality, op.cit., n.16 above.

37 KPMG, Conditional Fees Business Case (1998).

38 Shapland et al, op. cit., n.34 above. 
time and money necessary in such claims. ${ }^{39}$ Both small and specialist firms, it was predicted, would find it particularly difficult to adapt. ${ }^{40}$

Of course, access to justice also now depends on the willingness of the market to engage in risk because "the decisions we make are as much conditioned by our wish to take risk as our assessment of chance". ${ }^{41}$ Lawyers can take a number of different approaches to conditional fee work. They may:42

- take a mix of cases, some with low risk but relatively certain returns and some involving more risk but with higher potential returns;

- seek to minimise uncertainty by being extremely selective in the types of cases handled, and in particular, by focusing on routine cases which involve less uncertainty about the outcome, relatively predictable investment costs and achievable returns, such as road traffic accident claims;

- be relatively non-selective and minimise their investment in most cases with the aim of achieving lots of small recoveries with relatively little investment.

Not all of these approaches involve engaging with risk to secure optimal access to justice. In considering whether CFAs are facilitating access to justice, therefore, it is necessary to consider the extent to which lawyers and ATE insurers are both able and willing to engage in risk.

\section{The CFA Market in England and Wales: 2000-2004}

Whilst evidence suggests that approximately 2,363,233 personal injury claims were commenced between $1^{\text {st }}$ April 2000 and $31{ }^{\text {st }}$ March 2004 ${ }^{43}$ the number of these claims pursued on a CFA basis is unclear because data on funding is not collated centrally. ${ }^{44}$ Given the withdrawal of legal aid, a significant proportion of these claims must have been funded on a CFA basis, although before-the-event legal expenses insurance (BTE insurance) is playing an increasingly important role in facilitating access to justice and may even be more common than CFAs, particularly in road traffic accident

39 ibid., at p.79.

40 ibid., at pp. 83-84.

41 Higham, "Does Justice Play Dice? Can Lawyers Predict the Chances of Success in Litigation?" (2003) 12(1) Nottingham Law Journal 20, at p.25.

42 Op. cit., n.31 above.

43 Excluding clinical negligence claims. Data on the number of claims has been obtained from the Compensation Recovery Unit, which is collated pursuant to the Social Security (Recovery of Benefits) Act 1997 (c.27). See further, n.17 above.

44 Some information is available from the Legal Services Research Centre's first national periodic survey of justiceable problems conducted between July and October 2001. Advice relating to personal injury was provided on a CFA basis twenty seven per cent of the time, although it was noted that this percentage is likely to have risen, as the survey extended back to before the withdrawal of legal aid for such claims: Pleasence et al, op. cit., n.29 above, at p.82. Lack of information on CFAs is a general problem, as important data is now held by the fragmented market of liability insurers, ATE insurers, claimant lawyers and claims intermediaries and is often subject to commercial confidentiality. 
claims. ${ }^{45}$ A market research company has suggested that ATE insurers are insuring approximately 200,000 cases per annum and The Accident Group alone had pursued at least 250,000 CFA cases by May 2003. ${ }^{46}$ Approximately 75,000 legal aid certificates were issued annually in personal injury claims before its withdrawal ${ }^{47}$ and so the evidence suggests that the CFA market is supporting a larger number of claims than legal aid did before its withdrawal.

It does not appear, however, that CFAs have led to a sustained 'explosion' in the number of claims, as often alleged by the media and liability insurers. ${ }^{48}$ Data on the number of claims pursued prior to April 2000 is unavailable and so it is not, therefore, possible to identify trends in claims numbers before and after the introduction of CFAs in 1995 or CFAs with recoverability in 2000. Since April 2000, the number of claims has, in fact, been fluctuating:

The number of personal injury claims commenced in England and Wales (excluding clinical negligence claims): 2000-2004 ${ }^{49}$

$\begin{array}{llll} & \text { Accident Claims } & \text { Disease Claims } & \text { Total } \\ 2000 / 2001 & 601,230 & 123,800 & 725,030 \\ 2001 / 2002 & 604,353 & 74,183 & 678,536 \\ 2002 / 2003 & 607,573 & 91,147 & 698,720 \\ 2003 / 2004 & 550,077 & 213,045 & 763,122\end{array}$

The significant increase in disease claims in 2003/2004 is likely to relate to the Government's compensation scheme for coal-related respiratory disease, rather than CFAs. ${ }^{50}$ The increase in accident claims between 1999 and 2003 does coincide with the introduction of CFAs, although it may not solely be attributable to CFAs, as it appears that the increases may be part of a general trend. ${ }^{51}$ In addition, the number of accident claims fell in 2003/2004, which

45 See Genn, op. cit., n.29 above, at p.167; Pleasence et al, op.cit., n.29 above, at p.82 and Fenn and Rickman, Cost of Low Value Road Traffic Accident Claims 1997-2002: A Report Prepared for the Civil Justice Council (2003).

46 Master O'Hare, "Costs: Latest News" (2003) 153 N.L.J 782, at p.792.

47 Pleasence and Maclean, "Can Solicitors Pick Winners?" (1999) 149 N.L.J 138.

48 These allegations are made within the context of the "compensation culture" debate. See further: Furedi, Courting Mistrust: the hidden growth of a culture of litigation in Britain (1999); Lee, Debating Matters - Compensation Crazy: Do We Blame and Claim Too Much? (2002); Institute of Actuaries, The Cost of Compensation Culture (2002); Better Regulation Task Force, Better Routes to Redress (2004) and the Department for Constitutional Affairs' response to the Better Regulation Task Force report, Tackling the "Compensation Culture" (2004).

49 Op. cit., n.17 above.

50 The Department for Trade and Industry operates this scheme for those injured whilst working for British Coal. See further: <http://www.dti.gov.uk/coalhealth/ index.htm>.

51 Data on the number of clinical negligence claims, for example, shows that there has been a significant increase in the number of such claims since the late 1970s: Department of Health, Making Amends - A Consultation Paper Setting Out Proposals for Reforming the Approach to Clinical Negligence in the NHS (2003), at p.58. Similarly, the number of claims reported to the Compensation Recovery 
may suggest that recent increases are unsustainable, and if they continue to fall, will certainly raise cause for concern about the capacity of CFAs to facilitate access to justice.

The fact that the CFA market has, to date, supported a large number of personal injury claims does not, of course, mean that it is a viable alternative to legal aid. Comprehensive information on the approach of the CFA market is, as yet, unavailable. The early indications are, however, that Shapland et al's concerns were justified, as it appears that CFAs are facilitating access to justice for only some of those claimants who would previously have been eligible for legal aid - those with claims which are perceived to be lower risk claims in the context of the CFA market.

Lawyers have reported that "the way to make money out of CFAs" is to have "a regular throughput of small, easy cases". 52 Such cases are attractive because they tend to be cheaper to pursue, and as they conclude quickly, provide steady cash flow. ${ }^{53}$ They are also reported to offer good return for little risk. ${ }^{54}$ Cash flow appears to be a particular problem for small firms ${ }^{55}$ and a number of them have abandoned personal injury work, though it is not clear how many have done so or what the effect on the geographical availability of services has been. ${ }^{56}$

The need to secure a steady influx of 'bulk standard' cases for cash flow purposes has, however, caused problems in itself because it is expensive to generate these claims through advertising. Some solicitors share the costs with other solicitors by joining advertising networks. ${ }^{57}$ Another approach is to work with claims intermediaries, which 'farm' claims through mass advertising and direct marketing and then refer them onto solicitors. The presence of such companies in the market has caused considerable concern, as they are unregulated ${ }^{58}$ and are perceived to operate unethically. Concern has, for example, been expressed about the pressurised marketing tactics used by such companies. ${ }^{59}$ In addition, Claims Direct was heavily criticised

Unit (Northern Ireland) increased from 25,178 in 1994/1995 to a peak of 43,407 in 1998/1999, though by 2003/2004 it had fallen to 32,803: op.cit., n.17 above.

52 Goriely et al, More Civil Justice? The Impact of the Woolf Reforms on Pre-action Behaviour (2002), at p.21.

53 It appears that there is a correlation between the level of damages and costs: ibid., at p.177.

54 ibid., at pp.20-21. During their research on legal costs in employers' liability claims, Fenn and Rickman drew the tentative conclusion that damages are falling in CFA cases in comparison with non-CFA cases, which also suggests that CFAs are more common in relation to lower value claims: Fenn and Rickman, Costs of Low Value Employers' Liability Claims 1997-2002 (2003).

55 Op. cit., n.52 above, at p.19.

56 ibid., at p.24.

57 For example, InjuryLawyers $4 \mathrm{U}$ is "a consortium of leading personal injury solicitors" established to "promote direct access for injured people to the solicitors who will deal with their case": http://www.injurylawyers4u.co.uk/.

58 Better Regulation Task Force, op. cit. n.48 above, at p.20.

59 National Association of Citizens Advice Bureau, Door to Door: CAB Clients' Experiences of Doorstep Selling (2002). The Government is now consulting on how to tackle to this problem, which is not exclusive to the claims intermediary market: Department of Trade and Industry, Doorstep Selling and Cold Calling (2004). 
when it was discovered that it required claimants to unexpectedly pay substantial legal costs, leaving them with only a small fraction of their compensation $^{60}$ and The Accident Group is reported to have pursued fraudulent claims. ${ }^{61}$ Both of these companies have now collapsed, as their business models were unsustainable, ${ }^{62}$ although many smaller such companies continue to operate. ${ }^{63}$ The Government has now accepted that the sector should be regulated but has given it, through the Claims Standards Federation, one last chance to self-regulate and improve standards. ${ }^{64}$

Securing a steady stream of income from lower risk cases does not seem, however, to necessarily allow solicitors to support the higher risk claims. Yarrow's CFA survey, conducted prior to, but published after, the withdrawal of legal aid, found that whilst solicitors did not tend to rule out offering CFAs in particular categories of case, high risk and expensive disbursements were provided as reasons for excluding cases. ${ }^{65}$ Solicitors have also reported difficulties in taking riskier cases since the withdrawal of legal aid and have noted that many cases, particularly cutting edge cases, are not receiving funding. ${ }^{66}$ It seems that specialist firms find it difficult to find the resources to invest in the higher value, higher risk, complex caseloads which they usually attract. ${ }^{67}$ Whilst disbursement loans, which are now available to claimants, are of some assistance, they do not, therefore, appear to be alleviating solicitors of the financial burden which CFAs place on them. There is also some evidence that solicitors are averse to taking risks. ${ }^{68}$

The impact of CFAs on barristers is unclear. In Yarrow's early study there was very little evidence that solicitors were unable to find barristers to take on CFA cases. ${ }^{69}$ In 2001, however, Goriely et al found that solicitors were making less use of counsel and whilst there were several reasons for this, one was that barristers were finding CFAs financially difficult. ${ }^{70}$ Barristers are likely to be finding CFAs financially difficult for a number of reasons. As barristers are sole practitioners, they are unable to spread the risks posed by CFAs across several fee-earners, as solicitors' firms usually can. In addition, as a large majority of personal injury cases settle, those that go to court and

60 This was revealed by BBC One's Watchdog programme on 26 October 2000.

61 Op. cit., n. 48 above, at p. 21 .

62 See further: Better Regulation Task Force, op. cit., n.48 above; Datamonitor, UK Personal Injury Litigation 2003 - Where Does the Industry Go From Here? (2003), at p.92.

63 On the future of the claims intermediary market, see: Datamonitor, ibid., at p.130; A.Parker, "Where there's blame. .." (2004) 154 N.L.J 914.

64 Tackling the "Compensation Culture", op.cit., n.48 above, at p.5. The regulation of claims management companies was not dealt with in the context of Sir David Clementi's review of the Regulatory Framework for Legal Services in England and Wales.

65 Yarrow, op. cit., n.13 above, at p.5.

66 Op.cit., n.52 above, at pp.20-21.

67 ibid.

68 See Yarrow, op. cit., n.13 above; White and Atkinson, op. cit., n.13 above, and Goriely et al, op. cit., n.52 above.

69 Yarrow, op.cit., n.13 above, at p.12. Although Yarrow did find that barristers were used relatively infrequently in CFA cases, possibly because the CFA cases selected were straightforward and did not require a barrister.

70 Op. cit., n.52 above, at pp.52-54. 
involve the instruction of a barrister tend to be complex claims where the risk of losing, and receiving 'no fee', is higher. Barristers do not, therefore, have the same opportunity as solicitors to attract a large number of 'small, easy cases'. Further, as leading personal injury barrister, Nigel Cooksley QC, states:

"If you lose a case at trial, a hundred uplifts on [for example] advices or particulars of claims on settled cases won't cover that. It is difficult for the Bar to make ends meet and it makes our income extremely volatile". ${ }^{71}$

In response to these difficulties, the Bar Council has called for barristers to be paid as disbursements ${ }^{72}$, although it has also been suggested that barristers should be allowed to pool risk across chambers. ${ }^{73}$

It seems, however, that even if lawyers are willing to work on a CFA basis in higher risk claims, considerable difficulty can be experienced in securing ATE insurance for such claims. ${ }^{74}$ Solicitors are understandably reluctant to proceed without the costs protection provided by such insurance and ATE insurers have thereby become the 'gatekeepers' of access to justice. ${ }^{75}$ There are now approximately thirty ATE insurers offering a variety of insurance products. ${ }^{76}$ Many offer to defer the payment of the premium until the end of the case and some even waive the premium if the case is lost (so called, magic bullet schemes). ${ }^{77}$ This certainly assists many claimants with the upfront costs of CFAs and relieves them, and their solicitors, of some of the financial burden of CFAs. Some ATE insurers offer insurance on a delegated authority basis through panels of solicitors. This generally means that cases taken by solicitors on their panel are automatically insured, although it has been reported in 2000 that ATE insurers have sought success rates as high as 95 per cent from panel solicitors. ${ }^{78}$ Other ATE insurers underwrite cases individually, although it seems that claims with prospects of success between 50 and 60 per cent are difficult, if not impossible, to

71 Robins, "Bar's Anti-CFA Feeling Grows" (2003) 23 Litigation Funding 2.

72 "Barristers seek CFA exemption" (2003) 26 Litigation Funding 1.

73 Graham-Campbell, "Silk Purse from the Bar's Fear" (2004) 30 Litigation Funding 16. See also, Kunzlik, "Conditional Fees: The Ethical and Organisational Impact on the Bar" (1999) 62 M.L.R 850.

74 For a recent outline of the difficulties see Ward, "Just a little bit of lateral thinking" (2004) 31 Litigation Funding 8 and Datamonitor, op. cit., n.62 above.

75 Society for Advanced Legal Studies Report on the Ethics of Conditional Fees (2001), at para.3.104.

76 During Master O'Hare's review of the ATE insurance market, he was informed that there were 26 ATE insurers and a further 30 claims intermediaries and referral agencies which were also involved in the ATE market: Callery v Gray [2001] 4 All ER 1, at p.20. For further information on the ATE products available, see 'How the Products Compare' section in each bi-monthly issue of Litigation Funding.

77 For example, Abbey Legal Protection's Accident Line Protect policy. See further: Robins, “A Magic Bullet?” (2000) 6 Litigation Funding 6.

78 Moorhead, op.cit., n.4 above, at p.485. Lawyers risk being removed from the panel if they do not achieve targets set by ATE insurers. This raises ethical concerns, on which see op. cit., n.75 above. 
insure. ${ }^{79}$ It also seems that ATE insurers are reluctant to insure certain types of claims involving, for example, psychiatric injury, stress, deep vein thrombosis, repetitive strain injury, ${ }^{80}$ industrial disease ${ }^{81}$ and pharmaceutical products. ${ }^{82}$ In this sense the ATE market is probably indiscriminate. Insurers often approach their business on the basis of categories, rather than determining actual risk in individual cases. Good cases can, therefore, be excluded from cover because they belong to risky categories.

For the moment, therefore, it does not appear that CFAs achieve equality before the law, as the extent to which the potential financial barriers are removed depends on the nature of the claim. Whilst CFAs generally work well in relation to low risk cases, it does not appear at this stage that CFAs are a viable alternative to the legal aid system which it replaced, as evidence suggests that claimants with higher risk claims are experiencing difficulties in pursuing their claims. It should be noted, however, that the extent of this problem is unclear, as comprehensive information is not yet available. It may be that the CFA market as a whole can respond to facilitate access to justice, but that claimants must locate that part of the market which is able and willing to help. The fact that the local solicitor on the claimant's high street in Aberystwyth is unwilling or unable to take her case on a CFA basis does not mean that a solicitor in Swansea would react in the same way. As noted, it very much depends on firms' individual financial characteristics at the relevant time. Access to justice in the CFA market depends to a significant extent, therefore, on the advice given by the solicitor initially consulted and on the persistence of the claimant.

\section{Preliminary Problem or Fundamental Flaw?}

As only limited information on the CFA market is available, it is unclear how much of the problem relates to the financial inability of the market to deal with higher risk claims and how much relates to risk aversion. Nor is it clear whether the problem is a permanent feature of the market or a short term issue relating to its immaturity. It has certainly been difficult for those operating within the market to date, as they have, to a certain extent, been operating within a skills and information vacuum.

It is, for example, taking some time for lawyers to develop the risk management skills necessary to run a successful CFA practice. Research conducted prior to the withdrawal of legal aid suggested that lawyers' skills were lacking in this area and that many failed to monitor their progress on the risks they were taking. ${ }^{83}$ In deciding whether their firm can afford to take risk on a particular claim, lawyers must be able to assess: the claim's prospects of success; how much it will cost to support; how much it would cost if it lost and how long it might take to conclude. The lawyer must then

79 Gilbert, "The ATE Legal Expenses Insurance Marketplace: An Overview” (2004) J.P.I.L 99, at p.101.

80 "Facing the Future of Funding" (2004) 30 Litigation Funding 2, at p.7.

81 Rohan, "Clients in sickness and in health" (2002) 20 Litigation Funding 4.

82 Ward, op.cit., n.74 above.

83 BDO Stoy Hayward, Conditional Fee Agreements: A Survey Compiled by BDO Stoy Hayward (1999); Shapland et al, op.cit., n.34 above, at p.8; White and Atkinson's study revealed that whilst lawyers thought they were good at risk assessment, ATE insurers did not, op. cit., n.13 above, at pp.129-130. 
translate the assessed risk into a success fee. It seems, however, that whilst lawyers are generally quite good at assessing prospects of success, they are not as good at assessing the other risks ${ }^{84}$. In particular, it seems that lawyers have difficulty predicting likely $\operatorname{costs}^{85}$ and setting success fees. ${ }^{86}$ David Marshall, a leading personal injury lawyer and CFA expert, stated in 2001 that after "years of writing, lecturing and working on CFAs, at last I believe that I now understand how to set success fees properly". ${ }^{87}$ This gives some indication of how lawyers with less expertise might have fared.

In addition, if lawyers and ATE insurers are to manage risks effectively, they must understand those risks. The problem to date is that relevant information has been unavailable. Information on the cost and length of claims has been in short supply, ${ }^{88}$ as has data on success rates in personal injury litigation. Whilst success rates in some areas of personal injury litigation are high, they are perhaps not as high as is often assumed. Whilst Fennell's study suggested that the success rate in road traffic accident cases was ninety eight per cent, ${ }^{89}$ recent data from the Compensation Recovery Unit suggests a lower success rate of eighty eight per cent. ${ }^{90}$ Lack of clarity on this issue has caused problems for, for example, The Accident Group which made business decisions on the assumption that the failure rate of the cases they were supporting would be approximately four per cent, but it was, in fact, just over thirty per cent. ${ }^{91}$

As noted earlier, in deciding whether to work on a CFA basis or insure a CFA case, lawyers and ATE insurers consider whether the risks justify the potential return and whether their financial position allows them to take the risk. It was not clear at the outset, however, what the returns would be. Winning claimants are entitled to recover reasonable success fees and premiums and this is determined retrospectively at the conclusion of a claim either by agreement between the parties or by order of the court. When recoverability was introduced, there was no guidance on the reasonableness of success fees and premiums in different types of claim, as it was expected

84 Op. cit., n.47 above.

85 ibid.; Rohan, "Weighing Up the Odds" (2004) 31 Litigation Funding 12.

86 Yarrow concluded that "the majority of low risk cases have an uplift which appears too high while about half the high risk cases have an uplift which is too low.", op. cit., n.13 above, at p.87; Shapland et al believed that "firms had not appreciated how one lost case might wipe out the success fees won on a large number of cases, particularly if that lost case were to involve a high level of costs", op. cit., n.34 above, at p.56.

87 Marshall, "Playing the Percentages" (2001) 14 Litigation Funding 11. See also Marshall, "Calculating the Price of Success" (2004) 29 Litigation Funding 12.

88 This was particularly so because new civil procedure rules were introduced at the same time as the withdrawal of legal aid and the introduction of recoverability. Information on both aspects is now emerging, see: Fenn and Rickman, op. cit., n.45 and n.54 above and Goriely et al, n.52 above.

89 Fennell, The Funding of Personal Injury Litigation (1994).

90 Marshall and Morris, "Resolving a burning fees issue" (2003) 26 Litigation Funding 12.

91 Sharratt v London Central Bus Co. and other cases (No.2) (The Accident Group Test Cases) [2004] 3 All E.R. 325. See also Datamonitor, op. cit., n.62 above, at pp.95-96. This reflects, in part, the selection of cases by The Accident Group, in addition to overall success rates in personal injury litigation. 
that this would, in time, be provided by the courts. In the interim, however, the market was essentially operating in a risk-based business blindfolded.

CFAs involve what are referred to in the insurance business as 'long tail' risks. The outcome of risks taken do not become clear until claims are concluded, which can take some time. ${ }^{92}$ It is still not clear, for example, what success fees lawyers need to recover to make CFAs both financially viable and attractive in higher risk cases or whether they have, on the whole, been recovering enough success fees or premiums to date to meet their liabilities. Judges have experienced considerable difficulties in assessing the level of recoverable success fees and premiums. On the one hand they must ensure that what they allow makes CFA work both economically viable and attractive, on the other they must ensure that they do not allow lawyers and ATE insurers to recover too much..$^{93}$ Success fees in low value road traffic accident and employers' liability claims have, however, now been fixed by the market itself on the basis of empirical research and these are likely to prove more accurate. ${ }^{94}$

It is also unclear whether the ATE insurance market is sustainable in the long term in competition with BTE insurance. The Court of Appeal decided in Sarwar v Alam $^{95}$ that claimants should not generally be able to recover the cost of ATE insurance where a BTE legal expenses insurance policy is in place because it is unreasonable to incur the extra cost. Insurers have in recent years flooded the market with BTE insurance by attaching it free of charge, or at little cost, to other insurance policies. As the principle underlying insurance is that the 'many pay for the few', it is not clear whether ATE insurers' can, in the long term, secure a sufficiently large market share of profitable cases to make ATE insurance viable. ${ }^{96}$

Until the relevant skills and information emerges, it seems likely that lawyers and ATE insurers will either be over-cautious or make expensive mistakes, which may have a detrimental impact on access to justice. There is certainly some evidence that this has already happened. The Court of Appeal recently held that only half of The Accident Group ATE insurance premium could be recovered from losing defendants ${ }^{97}$ and this decision contributed to its collapse. This had a significant effect on The Accident Group's

92 By 2002, for example, Accident Line Protect - the longest running conditional fee linked scheme - had yet to see all of the cases insured in 1996 conclude: Hartley, "Conditional Fee Agreements Insurance: Lessons from Scotland - An Insurers Perspective" (2002) J.P.I.L 399.

93 See further: Callery v Gray (No's 1 \&2) [2002] 3 All E.R. 417; Sharratt, op. cit., n.91 above. For a critique of the judicial approach to success fees and ATE premiums, see: Zander, "Where are we now on Conditional Fees? - or why this Emperor is Wearing Few, if any, Clothes" (2002) 65 M.L.R 919; Zander, "Where Are We Heading with the Funding of Civil Litigation?" (2003) 22 C.J.Q 23 and Friston et al, "Costs Law Brief" (2005) 155 N.L.J. 214.

94 Part 45, Civil Procedure Rules.

95 Sarwar v Alam [2001] 4 All E.R. 541; [2002] 1 W.L.R. 125. See further: Peysner, "Turning into Trouble" (2001) 10(2) Nottingham Law Journal 64.

96 David Lock, Parliamentary Secretary, Lord Chancellor's Department at the time recoverability was introduced has expressed concern on this point: Lock, "Funding Faces Tough Future" (2001) 16 Litigation Funding 6.

97 Sharratt, op. cit., n.91 above. 
underwriters, some of which have now withdrawn from the ATE insurance market. $^{98}$ It is likely to be some time yet before the market achieves the stability it needs to become a reliable facilitator of access to justice.

Considerable instability in the market has also resulted from the 'costs war' which has dominated and over-shadowed the CFA market since the introduction of recoverability. The corollary of recoverability is the right of liability insurers to challenge the level of CFA-related costs claimed by seeking a court assessment. Liability insurers have, however, consistently challenged the circumstances in which they should have to pay CFA-related costs, and the amounts they should pay, on a wide range of grounds, although their challenges have centred on the level of recoverable success fees $^{99}$ and ATE premiums ${ }^{100}$ and the enforceability of CFAs ${ }^{101}$. On the latter, liability insurers argued that if a solicitor had not complied with the client care requirements laid down in the Conditional Fee Agreement Regulations 2000, the CFA was unenforceable. In that event, a winning claimant could not recover their legal fees from them, as in accordance with the indemnity principle, a winning claimant cannot recover from the liability insurer more than she is liable to pay her own lawyer. This led to consistent 'fishing expeditions' whereby liability insurers sought to establish whether claimant lawyers had complied with the relevant regulations. Whilst some of the challenges stemmed from genuine uncertainties within the CFA system, such as the level of recoverable success fees, challenges relating to the enforceability of CFAs have generally been regarded as "destructive". ${ }^{102}$

As claimant lawyers and liability insurers were unable to agree costs, a significant number of cases went to court, and as decisions in lower courts were appealed, the majority of CFA cases were stayed pending the appeal court decisions. It was estimated, for example, that 150,000 cases were awaiting the House of Lords decision in Callery $v$ Gray ${ }^{103}$ on the reasonableness of success fees and ATE premiums. In short, the payment of claimant lawyers' fees and ATE premiums ground to a halt as each new challenge was surmounted and this continued for four years. Whilst the impact of the satellite litigation has not been measured, it has increased the cash flow difficulties posed by CFAs, which in turn, is likely to have affected lawyers' willingness and ability to take on, and invest in, new claims. The Association of Personal Injury Lawyers has reported that between forty to sixty per cent of its 5000 members' caseloads were affected by liability insurers' enforceability challenges and that it was having a serious effect on their cash flow. It was also noted that the delay and uncertainty caused by satellite litigation was having a damaging effect on those claimants that had

98 NIG, Goshawk and HBOS withdrew from the market as a result: Datamonitor, op. cit., n.62 above, at p.95. The Accident Group's collapse is reported to have cost Goshawk £38 million: Senior, "Accident Group Collapse Costs Goshawk £38m" The Times, 27 September 2003 (http://www.timesonline.co.uk).

99 Callery, op. cit., n.93 above.

100 Callery, ibid.; Sharatt, op. cit., n.91 above.

101 Sharratt, ibid.; Hollins v Russell and other appeals [2003] 4 All E.R. 590.

102 Baroness Scotland of Asthal QC, Parliamentary Secretary at the Lord Chancellor's Department at Association of Personal Injury Lawyers' Annual Conference, Brighton, 9 May 2003.

103 Op. cit., n.93 above, at p.428 per Lord Hoffman. 
paid, or borrowed money to pay, for disbursements on such things as medical reports and any ATE insurance premiums. ${ }^{104}$

Whilst senior judicial figures have called for the removal of recoverability to end the problems, ${ }^{105}$ efforts have instead concentrated on removing the grounds of dispute. For example, to end disputes on success fees, the Civil Justice Council has, with the assistance of the CFA market, fixed the level of recoverable success fees for some road traffic accident and employers' liability claims. ${ }^{106}$ In addition, to address disputes surrounding enforceability, the Department for Constitutional Affairs has introduced new regulations to abrogate the indemnity principle ${ }^{107}$ and is currently consulting on the removal of most client care provisions from regulations and shifting them instead to the professional rules. ${ }^{108}$ Whilst satellite litigation has slowed down for the moment, there are still fears that insurers will find new grounds to challenge CFA costs claimed. ${ }^{109}$ It is not yet clear, therefore, whether recoverability is a viable concept in the long term as liability insurers may still use it to undermine the operation of the CFA scheme.

\section{Are Conditional Fee Agreements Leading To The Under- Settlement Of Claims?}

As Levin and Boon state, a "central tenet of professional practice is that a lawyer should promote the interests of the client and avoid situations where those interests conflict either with the lawyer's own interests or with those of another client". ${ }^{110}$ One of the main objections to CFAs is that they challenge this premise, as they lead to the creation of a marketplace where economic interests are central. ${ }^{111}$ The predominant concern, which was raised in Northern Ireland, is that lawyers might under-settle a claim rather than risk 'no fee'. In addition, as Moorhead notes, there is a strong emphasis in the CFA system on closing cases to secure cash flow. ${ }^{112}$ The perception is that the interests of claimants, lawyers and ATE insurers are synonymous to the extent that they all want to achieve a recovery of compensation, as this

104 Sharratt, op. cit., n.91 above, at pp. 606-607.

105 Whilst speaking at the Association of Personal Injury Lawyers' Conference in November 2002: (2002) 99 (44) Law Society Gazette 3. This has, however, been rejected by the Government: "Lord Chancellor Rules Out Abolishing Recoverability" (2003) 26 Litigation Funding 1.

106 Op. cit., n.94 above.

107 Conditional Fee Agreements (Miscellaneous Amendments) Regulations 2003 (SI2003/1240). See also: Rohan "Light at the end of the CFA tunnel" (2003) 25 Litigation Funding 2, "Seeing CFAs in a good lite" (2003) 28 Litigation Funding 2 .

108 Making Simple CFAs a Reality, op. cit., n.16 above. See Robins "Breaking the Stranglehold of CFAs" (2004) 32 Litigation Funding 4, at p.5.

109 At a recent meeting of leading CFA market lawyers and insurers, hosted by the Department for Constitutional Affairs, views differed on the extent to which liability insurers would continue to challenge CFA-related costs claimed: "Roundtable Thrashes Out Indemnity" (2004) 32 Litigation Funding 1.

110 Boon and Levin, The Ethics and Conduct of Lawyers in England and Wales (1997), at p.267.

111 For a comprehensive account of the ethical risks posed by CFAs, see Society of Advanced Legal Studies report, op. cit., n.75 above.

112 Moorhead, op. cit., n.15 above. 
ensures that claimants are compensated, lawyers are paid and ATE insurers do not have to pay defendant's costs. These interests, however, diverge in relation to the amount of the compensation recovered, as whilst this remains important to the claimant, it may not to the others. ${ }^{113}$

The extent of the risk of under-settlement is certainly a matter for debate. In relation to contingency fee arrangements in place in the United States, Kritzer's research has suggested that lawyers regularly overlook their own short-term economic interests to protect their reputation. If they under-settle, not only could insurers see them as a 'soft touch' in the bargaining process, but it may also affect the number of clients seeking their assistance. ${ }^{114}$ In contrast, however, Thomason's research suggested that reputation did not prevent under-settling. ${ }^{115}$ In England and Wales, the impact of retaining or gaining a good reputation amongst claimants is unclear, but the central role of ATE insurers adds a further dimension to the debate. As lawyers and claimants will be keen to retain ATE insurance cover, ATE insurers can exert considerable control over whether offers of settlement should be accepted. Whatever the good intentions of lawyers, ATE insurers, which are more remote from the claimant and do not have professional duties to act in claimants' best interests, may indeed have less regard for battling on to achieve a higher settlement. The significant role of ATE insurers is of particular concern given that lawyers have questioned ATE insurers' judgement and the quality of the personnel making these crucial decisions. ${ }^{116}$

Whatever the risks may be, however, there is not yet any evidence to suggest that CFAs compromise the claimants' ability to achieve fair settlements, though this is not to say that it is not happening in practice. Yarrow and Abrams have noted that it is very difficult to establish, especially for claimants, whether conflicts of interests influence solicitors' handling of cases and negotiation of settlement. ${ }^{117}$ Whilst solicitors participating in their study recognised the potential conflict of interest when negotiating settlements, they "did not think it was difficult to give objective advice."118 Fenn et al's empirical analysis of the impact of different forms of funding on personal injury litigation, conducted prior to the removal of legal aid, found that different funding mechanisms did not appear to have a significant influence on the amount of settlement. ${ }^{119}$ In fact, CFAs appeared to produce

113 For a general discussion of the economic incentives of different funding arrangements and costs rules, see: Bevan et al, Contracting for Legal Services with Different Cost Rules (Lord Chancellor's Department Research Series, 1999).

114 Kritzer (2002), op. cit., n.31 above, at pp.773-776.

115 Thomason, “Are Attorneys Paid What They're Worth? Contingent Fees and the Settlement Process" (1991) 20 Journal of Legal Studies 187, at p.222. Moorhead notes that "the fee arrangements which Thomason studies are not "pure" contingency fees arrangements, but rather, they contain regulated contingent fees and a mixed contingent fee and hourly rate approach which may take it closer to a conditional fee-type model": op. cit., n.4 above, at p.482.

116 "Tea Lady Turned Down Our AEI" (2000) 8 Litigation Funding 11; Robins, "Who Assesses the Assessors?" (2000) 9 Litigation Funding 7.

117 Op. cit., n.13 above, at p.112.

118 ibid.

119 Fenn at al, The Impact of Sources of Finance on Personal Injury Litigation: An Empirical Analysis (Lord Chancellor's Department Research Series, 2002), at p.38. 
higher compensation awards than other funding mechanisms, including legal aid. ${ }^{120}$ More recently, however, Fenn and Rickman's analysis of employers' liability claims after the removal of legal aid has led them to tentatively conclude that damages in CFA cases are lower than non-CFA cases. ${ }^{121}$ This may provide some evidence of under-settlement, although in view of the fact that lower-value claims tend to be lower risk claims in the context of CFAs, it seems more likely that the finding relates to the nature of cases lawyers most commonly agree to conduct on a CFA basis. The evidence on the issue of under-settlement is, therefore, mixed and inconclusive.

\section{Have Conditional Fee Agreements Increased Costs?}

CFAs with recoverability are financially attractive to both claimants and the Treasury because the system shifts the cost of personal injury litigation away from them towards defendants and their liability insurers. ${ }^{122}$ A crucial question, however, is: are CFAs better value than legal aid? In comparing the assumed costs of individual cases under each system, Moorhead concludes that "CFAs are more expensive, not cheaper"123 because they involve the additional costs of success fees and ATE insurance premiums:

"Only if insurance premiums and success fees are kept very low will the cost of CFA funded litigation be similar to the cost of legal aid funded personal injury litigation. The likelihood is that CFA funded litigation will be considerably more expensive than legal aid funded litigation."124

Comprehensive data on the costs of CFAs is not, however, available and so it is not yet possible to compare the costs of CFAs and legal aid. ${ }^{125}$ Fenn and Rickman's recent research on legal costs in individual cases has, however, raised cause for concern. ${ }^{126}$ They collated and analysed costs data from a variety of sources in road traffic accident and employers' liability claims below $£ 15,000$. They discovered an increase in legal costs overall, and in particular, in relation to non-litigated cases between 2000-2002. ${ }^{127}$ Total costs $^{128}$ in non-litigated claims between these dates had increased by approximately $50 \%$ in both types of claim.

What was surprising, however, was that Fenn and Rickman did not attribute these increases to the recoverability of success fees and ATE insurance premiums. Their data allowed them to compare costs in CFA and non-CFA

120 Fenn et al, The Impact of Conditional Fees on the Selection, Handling and Outcomes of Personal Injury Cases (Lord Chancellor's Department Research Series, 2002), at p.49.

121 Op.cit., n.54 above.

122 Moorhead, op. cit., n.15 above, at p.159.

123 ibid., at p. 161 .

124 ibid., at p.164.

125 Fenn and Rickman note that data on costs and damages in road traffic accident claims from around April 2002 in RTA cases is highly unstable due to fluctuations in the volume and duration of settled claims and cannot be relied upon: op. cit., n.45 above.

126 Op. cit., n.45 and n.54 above.

127 Fixed costs have now been introduced for low value road traffic accident claims to address this problem. See further, Part 45 of the Civil Procedure Rules.

128 Combined base costs, disbursements, success fees and ATE premiums. 
cases. In relation to road traffic accident claims they concluded that there was little difference between CFA and non-CFA claims with respect to agreed base costs and disbursements and that success fees and ATE premiums remained a relatively small part of overall costs recovered from insurers. The data relating to employers' liability claims revealed that statistically there was not a significant difference between the overall costs of running a claim on a CFA (including additional liabilities) and a non-CFA basis. If anything, it was noted, CFA costs seemed slightly lower. As a result, they concluded in respect of both types of claim that evident increases in legal costs since 2000 could not "readily be ascribed to recoverability rules introduced in April 2000". ${ }^{129}$ Instead, they suggest that the increase has been caused by the Civil Procedure Rules, which were introduced around the same time and appear to have led to the front-loading of costs. ${ }^{130}$

These findings are difficult to understand in view of the additional costs of success fees and ATE insurance premiums that are incurred in CFA cases. Perhaps the key lies in Fenn and Rickman's tentative finding that whilst costs in CFA and non-CFA cases had risen in a similar fashion, damages in CFA cases appeared to have fallen. The risk is that CFA cases are concentrated in low value claims because they pose less financial risk to lawyers and are more affordable in terms of the investment of time and money required. In other words, rather than suggesting that CFAs cost the same as other forms of funding, Fenn and Rickman's data could reflect choices about the type of claims conducted on a CFA basis. If damages are lower in CFA cases, then it could be said that CFAs are indeed more expensive. If the same costs are paid but the damages are lower, this suggests that it could cost more to deliver each pound of compensation under CFAs than other funding mechanisms.

The cost implications of CFAs are, therefore, still unclear, although further data on this issue is expected from Fenn and Rickman in 2005. Unsurprisingly, therefore, it is difficult to assess the impact of CFAs on the level of insurance premiums. Premiums for employers' liability insurance have increased significantly recently, and in response, the Department for Work and Pensions has reviewed the reasons for these increases. The Association of British Insurers submitted that CFAs had increased the cost of employers' liability insurance by twenty five to thirty per cent ${ }^{131}$ and Zurich suggested that their premiums had increased by eight per cent to meet the added cost ${ }^{132}$. The Department of Work and Pensions found, however, that

129 Op. cit., n.45 and n.54 above.

130 The Civil Procedure Rules and the Pre-Action Protocol for Personal Injury Cases are intended to increase the number of early settlements through improved exchange of information at the earliest possible stage. It is believed that this has led to increased legal costs to be incurred in the early stages of claims (often referred to as the 'front-loading' of costs): Goriely at al, op.cit., n.52 above, at p. 172 .

131 Office of Fair Trading, An Analysis of Current Problems in the UK Liability Insurance Market (2003), at para. 9.31.

132 ibid. 
the available evidence was inconclusive and that further analysis was required to assess the impact of CFAs following the removal of legal aid. ${ }^{133}$

\section{Part Two: Should Conditional Fee Agreements Be Introduced In Northern Ireland?}

Does experience in England and Wales suggest that CFAs are a viable mechanism for funding the majority of personal injury claims in Northern Ireland? In short, no, or perhaps more accurately, not yet. Whilst CFAs are certainly more than a 'gimmick', they are far from being the 'godsend' that they appear to be in theory. CFAs do seem to be facilitating access to justice in lower risk claims but not necessarily higher risk claims. It appears that, to some extent, this is due to the immaturity of the market and the instability caused by both the information and skills vacuum and the 'costs war'.

Northern Ireland could certainly have a more positive experience of CFAs in the early stages, compared with England and Wales. Firstly, it could avoid a repetition of the satellite litigation which has taken place to date. Court decisions, which would apply in Northern Ireland, have, for example, clarified how the scheme should operate, such as when it is reasonable to enter a CFA or to take out ATE insurance and the circumstances in which CFAs are enforceable. In addition, new CFA regulations, which seek to remove grounds of dispute, could be replicated. ${ }^{134}$ It is not yet clear, however, whether new grounds of dispute will emerge or not, although the very existence of the recoverability mechanism provides the opportunity for challenges to continue in the future. Secondly, subject to the provision of adequate training, lawyers, ATE insurers and judges would start with a much clearer understanding of how CFAs work and how, for example, success fees and premiums should be calculated.

The fact that the introduction of CFAs may run more smoothly does not, however, mean that CFAs would facilitate access to justice effectively for even low risk cases in Northern Ireland for three reasons. Firstly, there are approximately 1650 solicitors operating within 500 private practices and approximately fifty per cent of these have sole principals. Overall, just under ninety per cent are in partnerships of three principals or less. ${ }^{135}$ It is feared that these small firms would find it difficult to absorb the financial risks posed by CFAs. ${ }^{136}$ The evidence from England and Wales suggests that small firms indeed struggle with CFAs, and in particular, with the cash flow problems posed by them. If small firms find it difficult to work on a CFA basis in England and Wales, this has a detrimental impact on the geographical availability of legal services, which is regrettable. Access to justice is not necessarily affected, however, if claimants can gain access to

133 Department for Work and Pensions, Review of Employers' Liability Compulsory Insurance: First Stage Report (2003), at pp.47-55.

134 Op. cit., n.107 above.

135 Law Society of Northern Ireland's submissions to the Northern Ireland Assembly, which are attached to the Assembly's Ad Hoc Committee Report on the draft Access to Justice (Northern Ireland) Order 2002 (2002).

136 Capper, op.cit., n.4 above, at p.144; Association of Personal Injury Lawyers' response to the Northern Ireland Court Service consultation on the draft Access to Justice (Northern Ireland) Order 2002 (2002). 
the larger firms in the jurisdiction, which are able and willing to take their claims. Plaintiffs in Northern Ireland, however, may experience more difficulty, as those larger firms do not exist. The Government has argued that solicitors' tradition of speculative funding and funding of disbursements in Northern Ireland would stand them in good stead for CFAs. ${ }^{137}$ This may be so but solicitors' ability to take and absorb financial risks would change without a stream of income from closed legal aid cases in both winning and losing cases, as they receive at present. In addition, the introduction of a preaction protocol in personal injury cases, which was recommended by the Civil Justice Reform Group, may lead to the front-loading of costs, as in England and Wales. ${ }^{138}$ Solicitors may find the resulting increased costs and disbursements in the early stages of a claim harder to sustain.

Secondly, evidence suggests that barristers find it difficult to work on a CFA basis. The effect of this on the conduct and outcome of claims in England and Wales may not, however, be as significant as in Northern Ireland where solicitors, as general practitioners, rely heavily on counsel for drafting and specialist advice. If barristers are unable to work on a CFA basis, solicitors could pay their fees as disbursements but this would add significantly to the cash flow problems experienced by solicitors in working on a CFA basis and may not be sustainable.

Thirdly, it has not yet been established that the Northern Ireland market is attractive to the 'gatekeepers' of civil justice - ATE insurers. The current market of approximately 40,000 cases may be too small, unless insurers operate their business in conjunction with, rather than separate from, England and Wales. In addition, whether they are acting rationally in doing so or otherwise, ATE insurers have particular regard for the skills of the solicitors who are conducting the claims they are insuring. They usually seek evidence of specialist skills in the personal injury field before providing insurance on a delegated authority basis and lawyers' skills can be a reason for refusing the provision of insurance in individually underwritten cases. ${ }^{139}$ This could be a problem in Northern Ireland, which is dominated by general, rather than specialist, solicitors.

It is simply unclear whether CFAs could support the majority of personal injury claims in Northern Ireland. The fact that civil disputes in Northern Ireland "tend to involve relatively small amounts and to be less complex than those in England and Wales" ${ }^{140}$ does not mean that the needs of those with higher risk cases, which must exist in the jurisdiction, should be ignored. One of the main problems is that we know very little about personal injury litigation in Northern Ireland and the economics of solicitors' firms and barristers. Very little information emerged during the Civil Justice Reform Group's review of civil justice on, for example, the cost of personal injury claims. These costs are hidden in practice by the existence of fixed costs,

137 The Way Ahead, op.cit., n.16 above, at p.21.

138 Op. cit., n.129 above.

139 Op. cit., n.79 above.

140 Civil Justice Reform Group, Review of the Civil Justice System in Northern Ireland (1999), at para. 2.15. 
which operate on a swings and roundabouts basis. ${ }^{141}$ The Group concluded that “. . . there [was] little up-to-date factual (as opposed to anecdotal) evidence of the nature and resolution of civil disputes in Northern Ireland". ${ }^{142}$ With fixed costs, plaintiff lawyers do not have to submit detailed bills of costs and they do not record the time spent on, or the cost of, individual claims. ${ }^{143}$ Whilst some information on success rates is available, this relates to the 1970s and up-to-date information would obviously be preferable. ${ }^{144}$ Until the risks involved in CFA work can be quantified and until the economic capacity of solicitors and barristers are understood, it is not possible to say whether CFAs could work in Northern Ireland. Without this information, it is not possible to say at what level the civil legal aid budget should be capped, as the extent to which legal aid should continue to be available to facilitate access to justice in personal injury claims will be unclear. An understanding of the capacity of the market will also be vital if legal aid is to be refused by the Commission in those cases where CFAs are believed to be available. If legal aid is refused in cases where there are actually no real prospects of conducting them on a CFA basis, then access to justice will be detrimentally affected. The Commission should, therefore, conduct or commission research into both the characteristics of personal injury litigation and the economic capacity of the current legal market. It may find that CFAs would only be viable with some consolidation within the legal services market. Alternatively, it may be that for CFAs to be viable, lawyers and ATE insurers must be able to recover significantly higher success fees and premiums than in England and Wales. ${ }^{145}$

Whilst there is insufficient evidence at this stage to justify replacing legal aid in personal injury claims with CFAs, should this preclude the introduction of CFAs to complement legal aid? A combination of legal aid and CFAs would be problematic in that it would discriminate against the poorest members of society. Whilst many claimants that pursue CFA funded personal injury claims do not have to make any financial contributions, those who are

141 "The Group undertook two surveys in an attempt to assess the cost of civil litigation in Northern Ireland, the first with the assistance of the Legal Aid Department and the second with the assistance of the Law Society of Northern Ireland and Crown Solicitor's Office - the randomly selected cases reviewed failed to offer a scientific basis for assessing the cost of litigation: ibid, at para. 5.4 .

142 ibid., at para. 2.17 .

143 On fixed costs, see: His Honour Judge Hart QC, "Complexity, Delay and Cost The County Courts in Northern Ireland" (2002) 53 N.I.L.Q 125.

144 "The number of claims [for damages for personal injury] in relation to the size of population was slightly greater in Northern Ireland than in the rest of the United Kingdom. A higher proportion of claims 96 per cent as compared to 86 per cent] resulted in payment, and the average sum paid [ $£ 699$ as compared to $£ 566$ ] was greater.": The Royal Commission on Civil Liability and Compensation for Personal Injury (1978), vol. II, at para. 514.

145 The Association of Personal Injury Lawyers has, for example, suggested allowing success fees of up to 200 per cent of lawyers' normal fees: APIL Response to Northern Ireland Court Service Consultation on the Draft Access to Justice (Northern Ireland) Order 2002 (2002). 
eligible for legal aid often do. ${ }^{146}$ Having said that, if CFAs are introduced, legal aid should continue to be available as a safety net.

In addition, much is still unclear about the wider implications of CFAs and so whilst there is not a clear case for accepting them, there is not a clear case for rejecting them either. It does not appear that CFAs have led to a sustained increase in the number of personal injury claims. Any increase in the number of claims is, however, not necessarily problematic, as this suggests that claimants are able to achieve access to justice. CFAs do appear to have facilitated the growth of claims intermediaries, which have, to a certain extent, engaged in unethical practices. The Government has now, however, turned its' attention to the regulation of the claims intermediary sector.

The extent of any under-settlement, if it is taking place at all, is also unclear. The paradox, however, of the economic incentives within the CFA system may be that they generally encourage lawyers and ATE insurers to act in the interests of groups of claimants rather than individual claimants. As previously explained, the extent to which lawyers and insurers are able to engage in the CFA market depends on their ability to manage financial risk across a profile of cases. If decisions on the level of settlements in individual claims are taken to preserve financial health and stability, this increases the chance that they will be financially able and willing to support other CFA claims. In addition, care must be taken not to exaggerate the potential problem of under-settlement. In relation to the under-settlement of claims, the Society for Advanced Legal Studies' Working Party on Ethics and Lawyer Fee Arrangements has stated:

"... it is not enough to establish that undesirable incentives are capable of arising under CFA-funded litigation. Some assessment of their prevalence and significance must be made in comparison with alternative fee arrangements, and weighed against the potential benefits offered by CFAs as a means of ensuring access to justice." 147

Legal aid also posed a risk of under-settlement, as lawyers may have preferred to settle claims and receive higher fees rather than fight on for more compensation and risk losing and receive lower fees. In addition, the risk of under-settlement is probably just as great, if not greater, under informal speculative funding arrangements, which are common in Northern Ireland. As CFA expert, Peysner, has noted, "[t]he difficulties are just different not necessarily worse". ${ }^{148}$ The CFA system should not be compared to an idealistic vision of a world where lawyers fight to the bitter end to achieve the highest possible compensation award for their clients. Genn's research on the bargaining process in personal injury litigation, demonstrated that the level of settlements achieved are already influenced by an economy

146 See further: Legal Aid, Advice and Assistance (Northern Ireland) Order 1981 and the Legal Aid (Financial Conditions) Regulations (Northern Ireland) 2003, op.cit., n.10 above.

147 Op. cit., n.75 above, at para. 2.54

148 Peysner, "Weakest link" (2001) 12 Litigation Funding 4. 
of skills and resources. ${ }^{149}$ Further, the civil procedure rules require that the time and money spent on claims is proportionate to their value and importance. ${ }^{150}$ In a system dominated by the negotiation of out of court settlements, claimants may frequently receive less than they may be legally entitled to, and in this sense, CFAs may not be the 'evil' of personal injury litigation, but instead, make a bad system worse.

The limited information available to date suggests that the additional costs of success fees and ATE premiums associated with CFAs have not significantly increased claims costs overall. Whilst, in theory, CFAs should be more expensive than other funding mechanisms, because of the additional costs of success fees and ATE premiums, they may not be in practice due to the way in which lawyers select or conduct CFA cases. The cost implications of a CFA market which does support higher risk claims may be quite different, and indeed, significantly more expensive.

Due to concerns about the limitations of and difficulties experienced by the CFA market in England and Wales in its first few years of existence, valid questions have been raised about whether CFAs should be replaced by, for example, contingency fees. ${ }^{151}$ As the market does now appear to be settling down, there are certainly grounds to continue with CFAs to see if their performance improves in the longer term, as significant reform in this area at this stage would lead to further upheaval and disruption. After four years of instability and uncertainty, this may be too much for the market to bear. CFAs should not, however, be introduced in Northern Ireland until more is known about their capacity to facilitate access to justice and their wider implications.

149 Genn, Hard Bargaining: Out of Court Settlements in Personal Injury Actions (1987).

150 Civil Procedure Rules, Part 1, rule 1.1(c).

151 See further: Better Regulation Task Force, op. cit., n.48 above; Zander (2003) op. cit., n.93 above; op. cit., n.80 above; (2004) 101 (13) Law Society Gazette 26. 